\title{
Decentralization and Fiscal Discipline in Sub-national Governments: Evidence from the Swiss Federal System
}

\author{
Markus Freitag* and Adrian Vatter ${ }^{\dagger}$
}

This article analyses the relationship between decentralization and the extent of fiscal discipline in the Swiss cantons between 1984 and 2000. From a theoretical point of view, decentralization and federalism can be associated with both an expansive and a dampening effect on government debt. On the one hand, decentralized structures have been argued to lead to a reduction of debt due to inherent competition between the member states and the multitude of veto positions which restrict public intervention. On the other hand, decentralization has been claimed to contribute to an increase of public debt as it involves expensive functional and organizational duplications as well as cost-intensive, often debt-financed, compromise solutions between a large number of actors that operate in an uncoordinated and contradictory way. Our empirical results show that in periods of prosperous economic development, the architecture of state structure has no impact on debt. However, the degree of decentralization influences debt in economically poor times: In phases of economic recession, administratively decentralized cantons implement a more economical budgetary policy than centralized Swiss member states.

Given current worldwide processes of territorial reorganization, federalism as an organizational principle has been gaining in attractiveness since the late 1980s, and decentralization is perhaps the most important trend in governance around the world (Elazar 1995; Ehlert, Hennl, and Kaiser 2007; McKay 2001; Rodden 2006a; Vatter 1999; Watts 1999). Advocates of federalism not only emphasize this type of government structure's merits in terms of its capacity for societal integration, but also argue that a decentralized and federalized state guarantees the protection of socio-cultural independence and the political autonomy of its member states. ${ }^{1}$ Moreover, federalism's peculiar mode of vertical power-sharing provides an additional control between the central state and the sub-national units and affords protection against power abuse. Furthermore, the division of the political system into further political and administrative levels facilitates fact-oriented, low-context

Konstanzer Online-Publikations-System (KOPS) URN: http://nbn-resolving.de/urn:nbn:de:bsz:352-opus-76868

URL: http://kops.ub.uni-konstanz.de/volltexte/2009/7686 
approaches to problem-solving as well as populist politics. Finally, political parties can test their leadership qualities in political subdivisions, thus increasing their chances on the national level (cf. Elazar 1994; Riker 1964, 1975).

The drawbacks of federal architecture are generally argued, for one thing, to include a complicated decision-making system which is obscure to the citizens. For another, the autonomy of the sub-national units is said to lead inevitably to socio-economic differences and thus to political and social instability. In economic terms, federal architecture is said to damage the economy, since the functional integration of the political levels sometimes leads to drawn-out negotiations, impeding urgent changes in fast-moving times (cf. Armingeon 2000; Laufer and Münch 1998; Scharpf 1994).

Competing hypotheses likewise prevail regarding the effect of decentralized governance structures on the degree of public debt (Ehlert, Hennl, and Kaiser 2007). On the one hand, there are proponents of the view that inherent competition between the sub-national units in decentralized polities dampens state intervention and, thus, public debt (Brennan and Buchanan 1980; Oates 1999; Rodden and Wibbels 2002; Tiebout 1956; Weingast 1995). On the other hand, empirical studies point to the tendency of federal states to incur larger government and fiscal indiscipline (Rodden, Eskeland, and Litvack 2003; Stein 1999; Wibbels 2000). In particular, the abundance of political and administrative actors on the different levels is considered to be cumulatively more expensive than corresponding instances in a unitary state. These two competing viewpoints form the starting point of this analysis.

This article addresses one of the most important challenges facing multi-tiered systems of government: fiscal indiscipline among sub-national governments. Do decentralized structures reduce the degree of government debt or does a federal structure increase the burden of public debt? This is the central question of our study. Our objects of analysis are the twenty-six Swiss cantons from 1984 to 2000. The method used is a macro-quantitative comparison. Since Switzerland with its twenty-six cantons' extensive competencies is among the most federal and decentralized countries in the world (Elazar 1994; Watts 1999), it seems justified to treat the cantons as units with distinct state character. At the sub-national level, major economic and socio-political competencies exist i.e., the Swiss federal state disposes of strongly decentralized revenue and expenditure structures (cf. Lijphart 1999, 38; Linder 2005). ${ }^{2}$ In scarcely, any other federal state do member states have such far-reaching competencies and rights of self-determination as the twenty-six cantons in the Swiss Federation. ${ }^{3}$

At least three reasons speak for a systematically comparative and empirical analysis of the relationship between the Swiss cantons' decentralized structures and their levels of debt. Initially, a comparative analysis of the Swiss cantons regarding the consequences of decentralized structures on the public budget suggests itself 
because the sub-national units vary considerably in terms of the autonomy of their local authorities (Freitag 2006; Freitag and Vatter 2006; Ladner 1994; Vatter 2002). Moreover, the unique politico-institutional fragmentation of the Swiss cantons permits a comprehensive analysis of the effects of the most diverse political and institutional foundations on government debt. Thus, it becomes possible to examine not only the importance of party government composition, but also, for instance, the influence of direct democracy. Second, and strikingly, there exist virtually no macro-quantitative comparative studies in this field of investigation. ${ }^{4}$ This is astonishing in view of the Swiss federal state's splendid conditions and barely to be surpassed advantages of location. Third, public debt has latterly been moving more and more into the center of public interest, not least because of Maastricht's budgetary stipulations. Budgetary restrictions were likewise introduced in various Swiss cantons in recent years. ${ }^{5}$ Moreover, the case of Switzerland is, to a certain extent, exceptional, since it is not only the country with the most active use of direct democracy at national and sub-national levels, but also possesses one of the most decentralized federal systems (Lijphart 1999). Furthermore, Switzerland has been ruled by grand coalition governments since 1959. The country has been said to have "the most special set of political institutions among European democracies" (Lane 2001, 2). Thus, while specifically in the European context the country represents a special case, there are some interesting patterns of similarities and differences at the sub-national level between Switzerland and the United States (U.S.). On the one hand, the differences concern the government and party system. On the other hand, the Swiss cantons and the U.S. states show important parallels, such as strong decentralization and direct democracy, and a relatively low degree of state intervention. Against this background, the analysis of our research question on the basis of the Swiss case seems particularly worthwhile.

Our analysis of the effect of decentralization on public debt will take place in four steps. The next section introduces relevant theories and hypotheses regarding the relationship between these two variables. We then present our research design and the data used. The ensuing section focuses on the empirical examination of the hypotheses and the results achieved. The article ends with conclusions.

\section{Theories and Hypotheses}

There are two competing schools of thought on the nature of the relationship between federal structures and public debt. While the first school assumes that decentralized government structures have a dampening effect, the second links federal structure to an expansive debt incurrence drive.

Proponents of the more prominent dampening hypothesis argue in the tradition of the economic theory of federalism (cf. Ehlert, Hennl, and Kaiser 2007; Kirchgässner and Pommerehne 1996; Oates 1999; Rodden and Wibbels 2002; 
Tiebout 1956). In doing so, they assume in very general terms that the decentralization of decision-making and financing competencies tends to lead to a restraint in state intervention and consequently to a reduced level of public debt. The views on the dampening effect of federal structures can be linked to the veto player theorem. This posits that the veto players constitutionally guaranteed by a democracy, in the shape of autonomous institutions, act as obstacles to unrestrained majority rule by the central government (cf. Tsebelis 2002). Originally conceived as an explanation for differences in policy change, the veto player theorem can equally be applied to the development of state intervention in general. Here, it indicates the following: The more institutional veto positions oppose a central government and the parliamentary majority supporting it, the more probably will policy change be blocked or slowed down, and the more reserved will state intervention be (Schmidt 2000). Federal state architecture, in particular, ranks among these veto players (Tsebelis 2002). ${ }^{7}$

Both theoretical lines of thought help the advocates of the dampening hypothesis to a number of arguments, which attest that federalism has a curbing effect on state intervention, and which conceive this type of government structure as an effective barrier to debt incurrence. For instance, one argument suggests that a large number of sub-national units slow down the activism of superior political actors through the multitude of sub-national or local veto positions. The latter are exploited, for example, by oppositional forces as a gateway in order to express their preference for a restrained degree of state intervention. The blockade constellation thus exacted reduces the dynamics of public expenditure, constrains socio-political innovative freedom, and dampens egalitarian efforts in general (Schmidt 1998, 223). Moreover, federal power-sharing in the shape of fiscal-political decentralization limits the central state's administrative and financial room for maneuver, which in turn constricts its planning and enactment of welfare-state politics (Obinger 1997, 1998, 46).

Brennan and Buchanan (1980) argue that the political competition induced by elections does not prevent governments, in their exercise of power, from pursuing an agenda which runs counter to the interests of the citizens. For this reason, there is an additional need for competition between as many local authorities as possible, since the splitting-up of the political system is concomitant with increased options for the migration into other local authorities and competitive pressure on the subnational or local policy-makers to pursue a politics of low expenditure. Following Scharpf $(1987,261 \mathrm{ff}$.), the differing degrees of fiscal centralization eventually limit the central state decision-makers' possibilities of action. In this process, fiscally decentralized systems (or a small centralized state budget) limit the efficient central state use of deficit-financed fiscal policy in view of high implementation costs.

Finally, a cumulative body of recent research suggests that the political and economic effects of federalism are complex, multidimensional, and often 
contingent on fiscal and political factors (for an overview of the literature, see Beramendi 2007; Rodden 2006b). In particular, two dimensions of the distribution of power in federations are regularly mentioned as the source of differences in the fiscal performance of federations. The main claim by Rodden (2006a), Rodden and Wibbels (2002) and others is that the macro-economic effects of federalism are especially contingent on the nature of the fiscal contract and the nature of the party system.

The argument regarding fiscal structure posits a direct link between taxing and spending responsibilities and fiscal indiscipline. "A key proposition of the 'fiscal illusion' literature is that when the link between taxes and benefits is distorted or broken, voters are less likely to sanction overspending by politicians" (Rodden 2002, 672). The most prominent example is the so-called "flypaper effect" based on the assumption that an increase in intergovernmental grants rarely lead to tax reductions, but rather stimulates much higher expenditures and ultimately leads to larger debts. In addition, recent studies show that long-term balanced budgets among sub-national governments are more likely to be adopted when the governments in question have wide-ranging taxing and borrowing autonomy or borrowing restrictions are imposed by the national government. On the other hand, large debts are to be expected when sub-national governments are simultaneously dependent on intergovernmental transfers and free to borrow (Rodden 2002, 2006a).

The argument invoking the nature of the party system goes as follows: If national political leaders have substantial capacities to discipline irresponsible regional party officials, it can be easier for the central government to implement a coherent policy agenda. "To the extent that self-seeking fiscal policies by their provincial partisan colleagues might undermine their ability to provide them, national party leaders try to use their leverage over appointments or nominations to create incentives for sub-national officials to internalise externalities when making fiscal decisions" (Rodden and Wibbels 2002, 507-508). Regional leaders may have incentives to cooperate not only in the shape of explicit hierarchical threats, but also simply because their electoral fates are determined by the success of their co-partisans at the federal level. In sum, we can assume that sub-national politicians may have more incentives to internalize externalities when making fiscal decisions if they face correspondingly more "electoral externalities" (Beramendi 2007; Rodden 2006a). Thus, strong integrated party systems with disciplined parties can be a solution to the underlying collective good problem.

The debate regarding the effects of state architecture on government debt is naturally controversial, and with a view to Belgium, Canada, and Spain, ample instances can be found which contradict the dampening hypothesis (cf. Rodden 2002, 2003; Rodden, Eskeland, and Litvack 2003). According to Wagschal (2003, 305), the effect of federalism should be modified as soon as centrifugal forces 
come to act within federal local authorities. These forces fuel debt incurrence, since on the one hand regional units willing to opt out need to be monetarily pacified. On the other hand, this type of constellation causes a struggle for economic resources between the sub-national units to emerge, so that the central state is obliged to pay out compensations (Fornasari and Webb 2000). Further, it is argued that federalism increases the number of actors eligible to negotiate and fosters heterogeneity of interests. The organizational duplications, long-winded decisionmaking processes, and considerations of individual interests which emerge from this tend to lead to expensive compromise solutions (Scharpf 1994). In addition, it is argued that a decentralized policy-making structure leads to uncoordinated actions on the part of the political actors (Wibbels 2000). The respective national and sub-national political decision-makers obey differing logics of action and are responsible to different electorates. In this view, federal structures, for instance, generate incentives for sub-national political elites not to comply with a national economy drive but instead to pursue an expenditure policy of their own.

The geographical fragmentation of a political system into many regional authorities can result in uncoordinated decisions which fail to exploit economies of scale in the use of public services. The outcome is an inefficient, expensive public infrastructure (Castles 1999; Schaltegger 2003). Ultimately, fiscal competition between local units for the mobile population is related to a dangerous "Race to the Bottom." In other words: Given the option of fiscally motivated migration for financially strong companies and individuals, authorities stand in a regional competition for justified tax levels. The consequence of this putative race for the most favorable tax rate is low government revenue and, where public services remain unchanged, the temptation to finance the latter via debt (cf. Sinn 1997).

The results of existing research on this topic vary greatly. Wagschal (1996, 232-249), for instance, finds a systematic relationship between federal structures and government debt: The more difficult it is for the state to raise taxes, the lesser the rate of borrowing. Moreover, state deficit is lower in federal states (cf. also Rodden and Wibbels 2002). Wibbels (2000), on the other hand, confirms the debtfostering effect of federal structures. Clingermayer and Wood (1995), for their part, find no connection between government structure and public debt.

\section{Research Design, Method and Data}

Based on existing theoretical explications, we are faced with two competing hypotheses. On the one hand, it is argued that decentralized and federalized structures can lead to a reduction of debt due to inherent competition between regional or local authorities and the multitude of veto positions which restrict public intervention. On the other hand, decentralization and federalism is claimed to contribute to an extension of public debt as it involves expensive functional and 
organizational duplications as well as cost-intensive, often debt-financed compromises between a large number of actors that operate in an uncoordinated and contradictory way.

Whether the expansive or reductive effects prevail is an empirical question and requires closer statistical analyses. These may be carried out both in the context of an international comparison and via a comparative assessment of sub-national constituents. The research units of the following empirical analysis are the twentysix Swiss cantons. Switzerland's cantons are ideally suited for a systematic empirical comparison because they meet the requirements of the most-similar cases design (Przeworski and Teune 1970, 15ff.): On the one hand, the cantons show a substantial degree of similarity with respect to consolidated structural elements, while on the other they differ considerably regarding executive power-sharing, the fragmentation of the party system, and the decentralization of fiscal and political powers. It is potentially less difficult to create Ceteris-Paribus conditions for a systematic comparison of sub-national systems than in a cross-national comparison, since the cantons have many characteristics in common that can be treated as constants.

Our dependent variable fiscal discipline is measured by the annual change of per capita government debt in the cantons. These values reflect the data provided for the cantons including their municipalities. ${ }^{8}$ Our source is the annual data held by the Swiss Federal Finance Administration. The degree of decentralization in a canton is our central independent variable. Although the theoretical literature distinguishes between different types of decentralization (fiscal, political, organizational-administrative), empirical research usually focuses on only one of these dimensions (Rodden 2002). To go a step further, we operationalize decentralization with three indicators. The first indicator (political decentralization) depicts the degree of municipal autonomy in the respective canton as experienced by the individual municipal clerks based on a survey (cf. Ladner 1994). The second indicator records the degree of fiscal decentralization using the approach developed by Lijphart $(1999,193)$. It denotes the tax revenue of the canton as a percentage of the total tax revenue of the canton and the municipalities. Finally, the degree of organizational-administrative decentralization is operationalized by the average number of persons per municipality in a canton, thus covering the administrative fragmentation with regard to the number of local authorities in a given canton (cf. Vatter 2002; Nüssli 1985, 186). The higher (lower) the proportion of small municipalities, the lower a canton's fiscal discipline with regard to the annual change in governmental debt.

The design of the fiscal structure is measured by the real per capita finance transfers from the Confederation to the cantons and municipalities (intergovernmental grants). Other dimensions of the fiscal arrangements such as the degree of cantonal borrowing or taxing autonomy cannot be calculated, due to the 
fact that all Swiss cantons have the same level of borrowing autonomy and all cantons have the same right to collect their own taxes (there is no variation between the cantons).

Rodden and Wibbels $(2002,509)$ use data on the percentage of state government controlled by the party of the federal chief executive as a proxy for the presence of electoral externalities (high levels of partisan similarity between the center and provinces should reflect mutual interdependence of co-partisans across different levels). In the case of the Swiss cantons, we could assume that some cantonal party leaders are more tied to national government than others and are thereby more constrained in their ability to incur debt.

Unfortunately, it is not possible to calculate for each canton the share of the state government controlled by the party of the federal executive, since both the national government and the cantonal executives are-without exception-broadly supported multiparty coalition governments (Vatter 2007, 203). As such, we are unable to accurately calculate the measure of electoral externalities for the Swiss federal system, as the national and sub-national executives are collegial bodies which represent all of the major parties (for the difficulties measuring electoral externalities for the Swiss federal system, see also Rodden and Wibbels (2002, footnote 52).

Besides its federal structure, direct democracy ranks among Switzerland's most important political institutions. The influence of direct democracy on the annual change of per capita cantonal debt is transformed into measurable variables using two indicators. First, we consider the constitutional design of the mandatory referendum for a certain expenditure level. Second, we scrutinize the influence of the actual use of popular rights via the number of financial referenda held per annum in the cantons. The socio-cultural dimension-significant for the Swiss cantons-is warranted via the inclusion of a dummy variable for the German Swiss cantons. ${ }^{9}$

Our choice of the remaining control variables is geared to existing comparative studies on this subject and primarily takes into account the party influence, type and size of government, and various socio-economic determinants (cf. Borelli and Royed 1995; Freitag and Sciarini 2001; Hahm, Kamlet, and Mowery 1996; Hallerberg and von Hagen 1999; Roubini and Sachs 1989; Wagschal 1996, 2003). The influence of party ideologies on debt is controlled via the partisan composition of the respective government (Hibbs 1977). In this, we consider the percentage stakes held in cantonal governments by left-wing parties (SP, Green) and/or rightwing parties (FDP, SVP). Our calculations include the number of governing parties and the degree of government stability.

Central determinants of socio-economic development represent the degree of urbanization (proportion of inhabitants who live in urban areas), the unemployment rate and the share of over sixty-four-year-olds in relation to the twenty to sixty-four-year-olds in the population. The source for all values is data held from the Federal Statistical Office. The calculations include the annual percentage of 
economic growth. All variables are conveyed as annual characteristics. In line with causal and theoretical considerations and inasmuch as they vary through time, the explanatory variables enter the calculations with a lag. Table 1 provides an overview of the individual variables, their operationalizations, and the relationships expected.

Our examination of the hypotheses draws upon pooled time-series crosssectional designs. ${ }^{10}$ Our research period spans the years between 1984 and 2000. The choice of period is guided by the availability of cantonal comparative data and the influence of the explanatory variables against the backdrop of disparate economic developments. ${ }^{11}$ This circumstance is allowed for by means of an appropriate division of periods (1984-1990 and 1991-2000). Whereas the 1980s were characterized by prosperous economic development, a major recession affected Switzerland and its federal units at the beginning of the 1990s (Freitag 2000).

\section{Empirical Findings}

Our empirical examination of the impact of decentralized structures on governmental fiscal discipline is carried out for each of the two periods using a total of six models. Regarding table 2, which reflects the prosperous period of 1984-1990 the estimations reveal little systematic influence of the degree of decentralization on the annual change in public debt in the Swiss cantons. Only the coefficient of administrative decentralization confirms the dampening hypothesis and testifies to the constraining effect of decentralization on annual new borrowing in a statistically significant manner. However, it must be noted that this effect is contingent to a high degree upon the inclusion of the canton Geneva. If this canton is excluded from the analysis, the effect of administrative decentralization vanishes. To sum up: In the 1980s, there was no systematic relationship between the extent of decentralization (whether political, fiscal, or administrative) and fiscal discipline in the Swiss cantons.

Similar findings emerge from the remaining political and institutional control variables, the actual use of direct democracy (the number of financial referenda held), the number of governing parties, government stability, and the partisan composition of government. With regard to the mandatory financial referendum, it must be pointed out that the relationship displayed in model 1 depends substantially on the inclusion of the canton Basle-City.

Two socio-economic determinants were significant in the development of new borrowing in Swiss cantons in the 1980s: transfers from the central state and the cantons' linguistic-regional identities. The higher the fiscal equalization payments made to a canton, the higher the canton's fiscal discipline in times of prosperous economic development. And French and Italian-speaking cantons were more likely to incur debt. All other socio-economic determinants remain without systematic influence on fiscal discipline between 1984 and 1990. 
Table 1 Variables, hypotheses and operationalizations

\begin{tabular}{|c|c|c|c|}
\hline Variable & Operationalization & Data sources & $\begin{array}{l}\text { Expected relationship } \\
\text { according to } \\
\text { operationalization }\end{array}$ \\
\hline $\begin{array}{l}\text { Annual change of per } \\
\text { capita government } \\
\text { debt }\end{array}$ & $\begin{array}{l}\text { Annual change of per } \\
\text { capita government } \\
\text { debt in CHF }\end{array}$ & $\begin{array}{l}\text { Federal Finance } \\
\text { Administration } \\
\text { (various volumes) }\end{array}$ & \\
\hline $\begin{array}{l}\text { Political } \\
\text { decentralization }\end{array}$ & $\begin{array}{l}\text { Degree of cantonal } \\
\text { municipal } \\
\text { autonomy }\end{array}$ & $\begin{array}{l}\text { Ladner (1994), with a } \\
\text { new value (3.0) for } \\
\text { Basle-City (con- } \\
\text { firmed by the } \\
\text { author) }\end{array}$ & $\begin{array}{l}\text { The higher (lower) } \\
\text { the degree of } \\
\text { municipal auton- } \\
\text { omy, the lower a } \\
\text { canton's fiscal dis- } \\
\text { cipline }( \pm)\end{array}$ \\
\hline Fiscal centralization & $\begin{array}{l}\text { Proportion of canto- } \\
\text { nal tax revenue of } \\
\text { total cantonal and } \\
\text { municipal tax } \\
\text { revenue }\end{array}$ & $\begin{array}{l}\text { Federal Finance } \\
\text { Administration } \\
\text { (various volumes) }\end{array}$ & $\begin{array}{l}\text { The more fiscally } \\
\text { centralized (decen- } \\
\text { tralized) a canton, } \\
\text { the higher its fiscal } \\
\text { discipline }( \pm)\end{array}$ \\
\hline $\begin{array}{l}\text { Administrative } \\
\text { centralization }\end{array}$ & $\begin{array}{l}\text { Average number of } \\
\text { persons per muni- } \\
\text { cipality in a canton } \\
\text { (logarithmized) } \\
\text { (small values corre- } \\
\text { spond to a high } \\
\text { number of small } \\
\text { municipalities in a } \\
\text { canton) }\end{array}$ & Own calculations & $\begin{array}{l}\text { The higher (lower) } \\
\text { the proportion of } \\
\text { small municipali- } \\
\text { ties, the lower a } \\
\text { canton's fiscal dis- } \\
\text { cipline }( \pm)\end{array}$ \\
\hline $\begin{array}{l}\text { Mandatory financial } \\
\text { referendum }\end{array}$ & $\begin{array}{l}\text { Dummy } \\
\text { (“1”= obligatory } \\
\text { financial } \\
\text { referendum) }\end{array}$ & $\begin{array}{l}\text { Stutzer (1999); Stutzer } \\
\text { and Frey (2000) }\end{array}$ & $\begin{array}{l}\text { The presence of a } \\
\text { mandatory financial } \\
\text { referendum furthers } \\
\text { the fiscal discipline } \\
(+)\end{array}$ \\
\hline $\begin{array}{l}\text { Annual financial } \\
\text { referenda }\end{array}$ & $\begin{array}{l}\text { Annual number of } \\
\text { cantonal financial } \\
\text { referenda held }\end{array}$ & $\begin{array}{l}\text { Année Politique } \\
\text { Suisse (various } \\
\text { volumes); Moser } \\
\text { (1983 ff.) }\end{array}$ & $\begin{array}{l}\text { The more often the } \\
\text { instrument of } \\
\text { financial referen- } \\
\text { dum is used, the } \\
\text { higher a canton's } \\
\text { fiscal discipline (+) }\end{array}$ \\
\hline Government stability & $\begin{array}{l}\text { Number of changes of } \\
\text { government per } \\
\text { year }\end{array}$ & $\begin{array}{l}\text { Année Politique } \\
\text { Suisse (various } \\
\text { volumes) }\end{array}$ & $\begin{array}{l}\text { The more instable the } \\
\text { government, the } \\
\text { lower a canton's } \\
\text { fiscal discipline (-) }\end{array}$ \\
\hline
\end{tabular}


Table 1 Continued

\begin{tabular}{|c|c|c|c|}
\hline Variable & Operationalization & Data sources & $\begin{array}{l}\text { Expected relationship } \\
\text { according to } \\
\text { operationalization }\end{array}$ \\
\hline $\begin{array}{l}\text { Number of governing } \\
\text { parties }\end{array}$ & $\begin{array}{l}\text { Number of parties in } \\
\text { government }\end{array}$ & Own calculations & $\begin{array}{l}\text { The more parties are } \\
\text { represented in the } \\
\text { government, the } \\
\text { lower the degree of } \\
\text { fiscal discipline (-) }\end{array}$ \\
\hline $\begin{array}{l}\text { Strength of left-wing } \\
\text { governing parties }\end{array}$ & $\begin{array}{l}\text { Proportion of canto- } \\
\text { nal government } \\
\text { seats held by left- } \\
\text { wing parties (SP, } \\
\text { DSP, Green, incl. } \\
\text { Free List) }\end{array}$ & $\begin{array}{l}\text { Année Politique } \\
\text { Suisse (various } \\
\text { volumes) }\end{array}$ & $\begin{array}{l}\text { The stronger (weaker) } \\
\text { the right-wing and } \\
\text { liberal parties in a } \\
\text { canton, the higher } \\
\text { its fiscal discipline } \\
(\mp)\end{array}$ \\
\hline $\begin{array}{l}\text { Strength of right-wing } \\
\text { governing parties }\end{array}$ & $\begin{array}{l}\text { Proportion of canto- } \\
\text { nal government } \\
\text { seats held by right- } \\
\text { wing parties (FDP, } \\
\text { SVP) }\end{array}$ & $\begin{array}{l}\text { Année Politique } \\
\text { Suisse (various } \\
\text { volumes) }\end{array}$ & $\begin{array}{l}\text { The stronger (weaker) } \\
\text { the right-wing and } \\
\text { liberal parties in a } \\
\text { canton, the lower } \\
\text { its fiscal discipline } \\
( \pm)\end{array}$ \\
\hline $\begin{array}{l}\text { Proportion of over- } \\
64 \text {-year-olds }\end{array}$ & $\begin{array}{l}\text { Proportion of over- } \\
\text { 64-year-olds in } \\
\text { cantonal resident } \\
\text { population } \\
\text { (logarithmized) }\end{array}$ & $\begin{array}{l}\text { Federal Statistical } \\
\text { Office (various } \\
\text { volumes) }\end{array}$ & $\begin{array}{l}\text { The higher the pro- } \\
\text { portion of elderly } \\
\text { people in a canton, } \\
\text { the lower its fiscal } \\
\text { discipline }(-)\end{array}$ \\
\hline $\begin{array}{l}\text { Degree of } \\
\text { urbanization }\end{array}$ & $\begin{array}{l}\text { Proportion of inhabi- } \\
\text { tants in urban areas }\end{array}$ & $\begin{array}{l}\text { Own calculations } \\
\text { based on Schuler } \\
\text { (1997) }\end{array}$ & $\begin{array}{l}\text { The more urban a } \\
\text { canton, the lower } \\
\text { its fiscal discipline } \\
(-)\end{array}$ \\
\hline Economic growth & $\begin{array}{l}\text { Annual real economic } \\
\text { growth }\end{array}$ & $\begin{array}{l}\text { Own calculations } \\
\text { based on data by } \\
\text { BAK } \\
\text { Konjunkturforschu- } \\
\text { ng Basel AG and } \\
\text { the Federal } \\
\text { Statistical Office }\end{array}$ & $\begin{array}{c}\text { The stronger the eco- } \\
\text { nomic growth, the } \\
\text { higher a canton's } \\
\text { fiscal discipline }(+)\end{array}$ \\
\hline $\begin{array}{l}\text { Rate of } \\
\text { unemployment }\end{array}$ & $\begin{array}{l}\text { Number of unem- } \\
\text { ployed in percen- } \\
\text { tage of the labor } \\
\text { force }\end{array}$ & $\begin{array}{l}\text { State Secretariat for } \\
\text { Economic Affairs }\end{array}$ & $\begin{array}{l}\text { The higher the } \\
\text { unemployment } \\
\text { rate, the lower a } \\
\text { canton's fiscal dis- } \\
\text { cipline (-) }\end{array}$ \\
\hline
\end{tabular}


Table 1 Continued

\begin{tabular}{|c|c|c|c|}
\hline Variable & Operationalization & Data sources & $\begin{array}{l}\text { Expected relationship } \\
\text { according to } \\
\text { operationalization }\end{array}$ \\
\hline $\begin{array}{l}\text { Federal monetary } \\
\text { transfers }\end{array}$ & $\begin{array}{l}\text { Annual real per capita } \\
\text { aid money trans- } \\
\text { ferred by the } \\
\text { Federal } \\
\text { Government to the } \\
\text { cantons and } \\
\text { municipalities }\end{array}$ & $\begin{array}{l}\text { Federal Finance } \\
\text { Administration } \\
\text { (various volumes) }\end{array}$ & $\begin{array}{l}\text { The higher the fiscal } \\
\text { equalization pay- } \\
\text { ments made to a } \\
\text { canton, the lower } \\
\text { its fiscal discipline } \\
(-)\end{array}$ \\
\hline $\begin{array}{l}\text { German speaking } \\
\text { cantons }\end{array}$ & $\begin{array}{l}\text { Dummy } \\
\qquad(“ 1 ”=\text { German } \\
\text { Swiss cantons })\end{array}$ & Own calculations & $\begin{array}{l}\text { French and Italian } \\
\text { speaking Swiss can- } \\
\text { tons exhibit a lesser } \\
\text { degree of the fiscal } \\
\text { discipline }(-)\end{array}$ \\
\hline
\end{tabular}

Table 3 displays the relationships for the period from 1991 to 2000 when Switzerland was in the midst of a major recession. Here, it is initially notable that all three indicators of decentralization influence, to a statistically significant degree, the annual change in governmental debt in periods of economic downturn, thus confirming the dampening hypothesis. The more decentralized a canton's political, fiscal, and administrative structure, the lower was its annual new borrowing per capita debt in the 1990s. Furthermore, compared to the previous period and with regard to the strength of the individual coefficients, the influence of decentralized state architecture on public finances increases. However, only the administrative structure is not sensitive to the exclusion of the most centralized Swiss cantons, i.e., Basle-City and Geneva. If we exclude one of the two (or both) from the estimation in model 4 or 5 , both the coefficients of political as well as fiscal decentralization lose their significance.

With regard to fiscal discipline in periods of economic recession in the 1990s in the Swiss cantons, only the administrative architecture of the sub-national political systems matters. Politically fragmented cantons with a high number of small local authorities and administrations economize more per annum than cantons organized in a centralized manner. Examples for this are the cantons Grisons, Uri, Schaffhausen, and Thurgau. Conversely, particularly cantons with a low number of small municipalities exhibit comparatively low fiscal discipline. This applies in particular to the cantons Basle-City and Geneva, and to smaller extent also to Basle-Country and Neuchâtel. 
Table 2 Pooled time-series models of the influence of political and socio-economic conditions on the annual change of government debt in the 26 Swiss cantons, 1984-1990

\begin{tabular}{|c|c|c|c|}
\hline Variable & Model 1 & Model 2 & Model 3 \\
\hline Constant & $2,455.7$ & $2,212.8$ & $1,537.5$ \\
\hline Political decentralization & $-55.1(81.3)$ & - & - \\
\hline Fiscal centralization $_{t-1}$ & - & $2.0(3.1)$ & - \\
\hline Administrative centralization & - & - & $215.3(101.9)^{* *}$ \\
\hline Mandatory financial referendum & $117.6(54.8)^{* *}$ & $104.0(70.6)$ & $101.4(72.2)$ \\
\hline Number of financial referenda $a_{t-1}$ & $18.7(23.9)$ & $22.1(24.0)$ & $20.4(23.2)$ \\
\hline Number of governing parties ${ }_{t-1}$ & $-43.3(43.2)$ & $-47.4(38.2)$ & $-35.6(37.4)$ \\
\hline Government stability & $59.0(129.7)$ & $64.4(135.2)$ & $64.9(129.0)$ \\
\hline $\begin{array}{l}\text { Strength of left-wing governing } \\
\text { parties }_{t-1}\end{array}$ & $2.2(6.4)$ & $2.7(6.0)$ & $4.1(5.6)$ \\
\hline $\begin{array}{l}\text { Strength of right-wing governing } \\
\text { parties }_{t-1}\end{array}$ & $-0.5(2.2)$ & $-1.4(2.0)$ & $-0.6(2.0)$ \\
\hline $\begin{array}{l}\text { Proportion of population over } 64 \\
\text { years old } \\
t-1\end{array}$ & $-185.1(467.8)$ & $-202.5(536.7)$ & $-253.2(489.9)$ \\
\hline Per capita economic growth t-1 $_{t}$ & $-17.6(25.9)$ & $-16.8(26.7)$ & $-13.9(26.3)$ \\
\hline Unemployment $_{\mathrm{t}-1}$ & $-125.2(109.2)$ & $-114.8(110.5)$ & $-127.4(105.1)$ \\
\hline Degree of urbanization & $-0.2(2.4)$ & $-0.2(2.6)$ & $-1.9(2.4)$ \\
\hline Federal monetary transfers $s_{t-1}$ & $-317.3(104.5)^{* * *}$ & $-334.4(103.9)^{* * *}$ & $-334.8(101.8)^{* * *}$ \\
\hline German speaking cantons & $-284.2(133.4)^{* *}$ & $-309.9(127.6)^{* *}$ & $-397.0(111.9)^{* * *}$ \\
\hline$\rho$ (rho) & 0.02 & 0.03 & -0.02 \\
\hline Wald test & 2311.0 & 584.9 & 1840.6 \\
\hline$R^{2}$ & 0.08 & 0.08 & 0.10 \\
\hline Number of observations & 182 & 182 & 182 \\
\hline
\end{tabular}

Notes: for the operationalization of the individual variables, see text. The table depicts the nonstandardized regression coefficients.

* Significant on the $10 \%$ level (two-tailed test).

** Significant on the 5\% level (two-tailed test).

*** Significant on the $1 \%$ level (two-tailed test).

Standard errors (in parentheses) are corrected for heteroskedasticity according to the "panel corrected standard errors" method and corrected for autocorrelation according to the PraisWinsten method (cf. Beck and Katz 1995; Kittel 1999; Kittel and Winner 2005).

Of the controlling political and socio-economic factors, only economic growth and-in two out of three estimations-the region to which a canton belongs remain significant. The higher the annual economic growth between 1990 and 2000, the lower the annual increase in debt. Moreover, French and Italian speaking Swiss cantons exhibit a lesser degree of fiscal discipline. All other variables fail to have any statistically significant effect on the annual change in governmental debt 
Table 3 Pooled time-series models of the influence of political and socio-economic conditions on the annual change of government debt in the 26 Swiss cantons, 1991-2000

\begin{tabular}{|c|c|c|c|}
\hline Variable & Model 4 & Model 5 & Model 6 \\
\hline Constant & $2,944.9$ & $1,324.8$ & -79.4 \\
\hline Political decentralization & $-212.9(73.8)^{* * *}$ & - & - \\
\hline Fiscal centralization $_{t-1}$ & - & $12.4(4.8)^{* *}$ & - \\
\hline Administrative centralization & - & - & $789.4(183.3)^{* * *}$ \\
\hline Mandatory financial referendum & $-103.9(109.0)$ & $-87.5(113.8)$ & $-135.3(115.4)$ \\
\hline Number of financial referenda $a_{t-1}$ & $-6.5(40.5)$ & $-12.3(39.8)$ & $0.1(40.1)$ \\
\hline Number of governing parties ${ }_{t-1}$ & $40.6(92.3)$ & $-12.3(94.4)$ & $-21.7(85.7)$ \\
\hline Government stability & $-7.4(146.6)$ & $-16.6(143.7)$ & $-36.6(131.6)$ \\
\hline $\begin{array}{l}\text { Strength of left-wing governing } \\
\text { parties }_{t-1}\end{array}$ & $-1.1(5.9)$ & $-0.9(5.6)$ & $2.6(5.2)$ \\
\hline $\begin{array}{l}\text { Strength of right-wing governing } \\
\text { parties }_{t-1}\end{array}$ & $1.0(2.9)$ & $-1.4(2.9)$ & $3.8(2.5)$ \\
\hline $\begin{array}{l}\text { Proportion of population over } 64 \\
\text { years old } t-1\end{array}$ & $661.9(598.5)$ & $597.5(526.7)$ & $385.2(476.4)$ \\
\hline Per capita economic growth t-1 $_{t}$ & $-63.2(23.6)^{* * *}$ & $-60.6(23.4)^{* * *}$ & $-66.2(23.1)^{* * *}$ \\
\hline 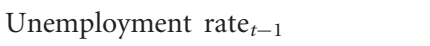 & $-80.7(54.0)$ & $-75.8(53.0)$ & $-79.5(50.1)$ \\
\hline Degree of urbanization & $2.9(3.2)$ & $4.7(3.0)$ & $-2.8(2.6)$ \\
\hline Federal monetary transfers ${ }_{t-1}$ & $-3.3(151.1)$ & $-1.6(147.4)$ & $-77.5(135.8)$ \\
\hline German speaking cantons & $-176.9(194.0)$ & $-300.2(168.9)^{*}$ & $-672.9(154.4)^{* * *}$ \\
\hline$\rho$ (rho) & 0.13 & 0.13 & 0.08 \\
\hline Wald test & 108.8 & 96.6 & 121.1 \\
\hline$R^{2}$ & 0.15 & 0.15 & 0.20 \\
\hline Number of observations & 260 & 260 & 260 \\
\hline
\end{tabular}

Notes: For the operationalization of the individual variables, see text. The table depicts the nonstandardized regression coefficients.

* Significant on the $10 \%$ level (two-tailed test).

** Significant on the $5 \%$ level (two-tailed test).

*** Significant on the $1 \%$ level (two-tailed test).

Standard errors (in parentheses) are corrected for heteroskedasticity according to the "panel corrected standard errors" method and corrected for autocorrelation according to the PraisWinsten method (cf. Beck and Katz 1995; Kittel 1999; Kittel and Winner 2005).

between 1990 and 2000. In summary, it can be concluded that during the economic recession in the 1990s, the German Swiss cantons-which display a comparatively strong degree of economic growth and are administratively fragmented, having a large number of small municipalities_notably handled public finances in a more economical manner than the economically weak and centralized cantons of French and Italian Switzerland. 


\section{Conclusion}

Our point of departure was the controversy regarding the contradictory consequences of decentralization on the extent of public debt. Our empirical results from twenty-six Swiss cantons in the 1980s and 1990s consolidate the view-endorsed in existing research—-that decentralized structures have a strengthening effect on the degree of fiscal discipline (Oates 1999; Rodden and Wibbels 2002; Weingast 1995). However, it is administrative decentralization-i.e., a large number of small, independent municipalities—not political and fiscal decentralization only that tends to lead to a restrained budgetary policy. In other words: The degree of political independence among different state levels and the extent of local tax sovereignty is less significant for public finances than the number of local administrations. The notable fiscal discipline of small local administrations can be accredited to their following characteristics: (i) the administrators tend to be part-time or volunteer (so-called self-administration), rather than full-time professional civil servants, thus resulting in lower personnel expenditures; (ii) information and control costs are lower in small bureaucracies than in larger administrations; (iii) small communes that compete with one another have weaker monopolies, closer proximity to citizens and better control of the administration than larger administrations. The effects of the last attribute of smaller administrations can be most acutely observed in times of economic recession and inherent distribution struggles. The present result is consistent with the findings of Lüchinger and Stutzer (2002) who found that after the fusion of small Swiss communes, economies of scale were not achieved; total public expenditures were rather shown to be higher following consolidation.

Of course, this finding is contingent upon economic development. Our empirical results show that in periods of prosperous economic development, the architecture of state structure has no impact on the rate of debt. However, the degree of decentralization does influence debt in economically poor times: In times of economic recession, administratively decentralized cantons are thriftier than centralized Swiss member states. Thus, fiscal discipline in cantons such as BasleCity, Geneva, and Neuchâtel, with their comparatively central state structures, is significantly lower than in cantons with a high degree of local administrative autonomy such as Grisons, Thurgau, and Aargau. Conversely, none of the present calculations can prove a heightening effect of decentralized structures on the annual increase in debt.

What generalizable conclusions can be drawn regarding the relationship between decentralization and rates of debt from the results at hand concerning the Swiss cantons? First, highly-developed decentralized administrative structures prove to be particularly effective as incentive systems - in a context of high societal stability, 
political and institutional security (strong property rights) and economic prosperity-for politicians to handle taxpayers' money in a restrained and responsible manner. Moreover, our empirical findings make clear that even very small political units are well suited to the implementation of an autonomous fiscal policy, considering that the Swiss cantons with the lowest populations (and often the lowest levels of debt) have only a few tens of thousands of inhabitants and many Swiss municipalities only have a few hundred inhabitants. Furthermore, the pronounced degree of competition between the sub-national units for mobile resources in the framework of Swiss competitive federalism also favors low levels of debt.

However, contrary to the results attained by Rodden (2002) and others, our empirical results for the 1980s show that lower deficit rates occur when subnational governments are more dependent on intergovernmental transfers. Surprisingly, heavy involvement of the federal executive in the financing of regional governments creates some incentives for fiscal discipline in times of economic growth.

Meanwhile, unlike vertical power-sharing, horizontal power-sharing in the shape of broadly supported government coalitions remains without influence on the rate of government debt. This confirms, on a sub-national level, the results of Hahm, Kamlet and Mowery (1996) and Wagschal (1996, 2003), whose international comparisons likewise find no systematic influence of oversized governments on budget deficits and public debt. In this vein, we are obliged to discard Roubini and Sachs' (1989) findings on the debt incurrence tendencies of large government coalitions.

Based on the results on hand, we can find no robust or systematic relations between direct democracy and the cantonal fiscal discipline between 1984 and 2000. In addition, partisan composition of government has no systematic influence on the annual development of the cantonal debt. This result can perfectly well be linked to the conclusions of comparative public policy research on the limited influence of party politics in consensus democracies: The more institutional barriers facing a central government and parliamentary majority, the less suitable is the party difference hypothesis-developed mainly for Westminster models-as an explanation of government action. Moreover, our results also confirm the suspicion that the party effect plays a less important role on the sub-national level, since discussions here are predominantly less ideological (cf. Wagschal 1996). Our results grant a certain degree of significance to socio-economic determinants. Here, it can be seen that notably in times of economic recession, economic growth contributes to economical budget management.

In terms of sub-national research into the cause-effect relationships between decentralized structures and fiscal performance, a particularly fruitful line of questioning for the future would seem to be a more detailed examination of the 
influence of, and the reciprocal interaction between, political and institutional incentive structures. Such an examination would also further advance the linkage between federalism research from the political science and economic perspectives. What influence do electoral rules, the structures of the regional party systems, and the decision-making rules within regional legislature have on the fiscal decisions of sub-national politicians? These open questions should be the subject of future investigations.

\section{Notes}

This article was written as part of a research project of the authors on institutional determinants of public policy at the cantonal level, which was carried out within the framework of the priority programme "Demain la Suisse" of the Swiss National Science Foundation (Project no. 50-58521.99). We would like to thank the four anonymous reviewers for their critical remarks and suggestions and Antje Kirchner for her technical support.

1. In order to avoid repetition, the terms "federalism" and "decentralization" are often used synonymously in the present article. We are, of course, aware of the difference between the two concepts. While federalism signifies the organizational principle for a polity in which legally equal units are affiliated within a super-ordinate political body and where for some of the central government's decisions the consent of the sub-national units is required, decentralization refers in particular to the delegation of government tasks to territorial units by the central state (Rodden 2004, 482ff.). In this article, we try to account for this difference through the fact that our empirical findings relate exclusively to the dimension of decentralization, and by consistently referring, in these sections, only to decentralization, not to federalism. In the theoretical section, meantime, we follow the lead of the greater part of the literature, which tends to concentrate on the effects of federal structures in this research area.

2. Thus Lijphart, for instance, in his preface to a study by Vatter $(2002,3)$, judges the research design chosen there as follows: "Because the Swiss cantons are cantons within the same national political system, there are many characteristics which they have in common, and which therefore may be treated as constants. The justification of focusing on the Swiss cantons is especially strong because they are powerful political entities in an unusually decentralized federation. Another advantage is that there are twenty-six cantons-a sufficient number of cases for statistical analysis."

3. The independence of the cantons from one another could be questioned, as some Swiss cantons deliver services (hospitals, universities, etc.) to neighboring cantons that are too small to provide such infrastructures themselves. However, the small cantons are obligated to remunerate the large neighboring cantons for infrastructure services purchased for their own cantonal populations (e.g., in the areas of health, education and culture) on the basis of bilateral agreements in accordance with the expenses incurred. Such remuneration takes into account both the investment costs and the ongoing costs incurred by the larger cantons for hospitals, universities, high schools, etc., with the aim 
of achieving the highest possible degree of fiscal equivalence (i.e., so that ideally, the payments made by a canton per patient, student, etc. for extra-cantonal services correspond to the total costs of the canton providing the financial support). In fact, the relatively high levels of remuneration cause the smaller cantons to try continually to provide many infrastructure services themselves. For instance, the fact that in Switzerland a total of twenty-six independent health care and educational systems still exist today is seen as a significant efficiency problem of the small-scale Swiss federal system. At the same time, however, this circumstance leads to the previously mentioned fact that the cantons can be considered relatively independent of each other and enjoy a high degree of autonomy, and that Switzerland continues to be notable for its highly developed competitive federalism.

4. Although a whole array of articles deals with the determinants of government debt on the national state as well as on the regional level, a mere handful of empirically comparative studies address the effect of decentralization on public debt. Exceptions are the studies by Clingermayer and Wood (1995), Fornasari and Webb (2000), Rodden (2002), Rodden and Wibbels (2002), Rodden, Eskeland, and Litvack (2003), Wagschal (1996), and Wibbels (2000).

5. Debt-braking instruments sometimes play a part in the cantonal constitutions, but they are primarily to be found in cantonal laws of finance. Means towards the limitation of government deficits can be found, sometimes with a considerable previous history, in St Gall (in force since 1997, Cantonal Law of Administration, Articles 61 and 64), Fribourg (1996, Cantonal Law of Finance, Articles 5 and 41, section 3), Solothurn (1995, adjusted corpus juris, 611.22, section 6), Appenzell Outer Rhodes (1996, Cantonal Law of Finance Articles 9 and 10), Grisons (1999, Cantonal Law of Finance, Article 3), Nidwalden (2001, Cantonal Law of Finance, Article 4), Zurich (2001, Cantonal Law of Finance, sections 4, 6, and 21; Cantonal Tax Law section 2), Lucerne (2001, Cantonal Law of Finance, sections 4 and 9), Bern (2002, Cantonal Law of Finance section 2; Cantonal Constitution Article 101a), Valais (2004, Cantonal Law of the Limitation of Public Deficits), Basle-City (2003, accepted by the state legislature) Ticino (2004, accepted by the state legislature), and Aargau (2004, accepted by the people). In St Gall, this implied the writing down of an over sixty-year-old practice.

6. Besides qualitative studies, recent comparative quantitative research also documents that the degree of state intervention can be traced back to the difference between federal and unitary state structures and to related decentralized power-sharing (cf. Braun 2000; Castles 1999; Keman 2000; Lancaster and Hicks 2000; Lane and Ersson 1997; Schaltegger 2001, 2003; Shadbegian 1999).

7. Recently, in particular, research projects have been taking advantage of the Swiss "laboratory's" site merits by carrying out macro-quantitative analyses of the effect of political institutions on state intervention (cf. Armingeon, Bertozzi, and Bonoli 2004; Feld and Matsusaka 2003; Schaltegger and Feld 2003).

8. Because cantonal per capita debt is nonstationary (i.e., this year's debt is a function of last year's debt) (cf. Hadri 2000; Im, Pesaran, and Shin 2003), we applied regressions of differenced data of the dependent variable including a Prais-Winsten transformation to remove autocorrelation. We are grateful to the reviewer for this suggestion. 
9. Results of federal ballots regularly indicate that the voting population in the German speaking Cantons tends to favor the concept of a slim, subsidiary state, while the Latin cantons favor political patterns with a more etatistic character. Thus, it is suspected that there is a negative connection between the proportion of German speakers and the extent of government debt.

10. We address the pitfalls of this method in the form of heteroskedasticity and autocorrelation as follows: To correct heteroskedasticity in the cross-section, we apply the White method for panel corrected standard errors. An even stronger distorting effect emanates from the serial correlation of the residuals (Kittel 1999; Kittel and Winner 2005). A possibility to model autocorrelation is to incorporate a lagged dependent variable. However, this method for its part leads to an underestimation of the actual significance of the politico-institutional variables, which, here is the principal focus of interest (Achen 2000, 16). Following Kittel (1999, 230-231), we thus use the PraisWinsten method to correct the distorted standard errors. On account of the small number of observation years, we estimate only one $\rho$ (rho).

11. Obviously, one of the reasons for subdividing the investigation period is a methodical argument: An estimation which covers the entire period runs the risk of "calculating out" individual directions of influence (perhaps which run inversely in the various periods), and of producing statistically insignificant estimations as averages. Moreover, there is a possibility that individual estimations may in fact influence a certain period only, but on account of their strength radiate their influence throughout the entire investigation period.

\section{References}

Achen, Christopher. 2000. Why lagged dependent variables can suppress the explanatory power of other independent variables. Article presented at the annual convention of the political methodology section of the American Political Science Association, July 20-22, UCLA.

Anneé politique Suisse (various volumes). Schweizerische Politik. Bern: Institut für Politikwissenschaft.

Armingeon, Klaus. 2000. Swiss federalism in comparative perspective. In Federalism and political performance, ed. Ute Wachendorfer-Schmidt, 112-129. London/New York: Routledge.

Armingeon, Klaus, Fabio Bertozzi, and Giuliano Bonoli. 2004. Swiss worlds of welfare. West European Politics 27 (1): 20-44.

Beck, Nathaniel, and Jonathan N. Katz. 1995. What to do (and not to do) with time-series cross-section data. American Political Science Review 89 (3): 634-647.

Beramendi, Pablo. 2007. Federalism. In Oxford handbook of comparative politics, eds. Carles Boix, and Susan C. Stokes, 312-354. Oxford: Oxford University Press.

Borelli, Stephen A., and Terry J. Royed. 1995. Government strength and budget deficits in advanced democracies. European Journal of Political Research 28 (2): 225-260.

Braun, Dietmar, ed. 2000. Public policy and federalism. Aldershot: Ashgate. 
Brennan, Geoffrey, and James Buchanan. 1980. The power to tax. Analytical foundations of a fiscal constitution. Cambridge: Cambridge University Press.

Bundesamt für Statistik (Federal Statistical Office, various volumes). Statistisches Jahrbuch der Schweiz. Bern/Zurich: NZZ.

Castles, Francis. G. 1999. Decentralization and the post-war political economy. European Journal of Political Research 36 (1): 27-53.

Clingermayer, James C., and B. Dan Wood. 1995. Disentangling patterns of state debt financing. American Political Science Review 89 (1): 108-120.

Ehlert, Niels, Annika Hennl, and André Kaiser. 2007. Föderalismus, Dezentralisierung und Performanz. Eine makroquantitative Analyse zur Leistungsfähigkeit territorialer Politikorganisation in entwickelten Demokratien. Politische Vierteljahresschrift 48 (2): 243-268.

Elazar, Daniel J., ed. 1994. Federal systems of the world. A handbook of federal, confederal and autonomy arrangements, 2nd ed. Harlow: Longman Current Affairs.

1995. From statism to federalism: A paradigm shift. Publius: The Journal of Federalism 25 (2): 5-18.

Feld, Lars P., and Matsusaka John G. 2003. Budget referendums and government spending: Evidence from Swiss cantons. Journal of Public Economics 87 (12): 2703-2724.

Fornasari, Francesca, and Steven B. Webb. 2000. The macroeconomic impact of decentralized spending and deficits. International evidence. Annals of Economics and Finance 1: 403-433.

Freitag, Markus. 2000. Soziales Kapital und Arbeitslosigkeit. Eine empirische Analyse zu den Schweizer Kantonen. Zeitschrift für Soziologie 29 (3): 186-201.

- 2006. Bowling the state back in: Political institutions and the creation of social capital. European Journal of Political Research 45: 123-152.

Freitag, Markus, and Pascal Sciarini. 2001. The political economy of budget deficits in the European Union. The role of international constraints and domestic structure. European Union Politics 2 (2): 163-189.

Freitag, Markus, and Adrian Vatter. 2006. Initiatives, referendums, and the tax state. Journal of European Public Policy 13: 89-112.

Hahm, Sung Deuk, Mark Kamlet, and David Mowery. 1996. The political economy of deficit spending in nine industrialized parliamentary democracies. Comparative Political Studies 29 (1): 52-77.

Hadri, Kaddour. 2000. Testing for stationarity in heterogenous panel data. Econometrics Journal 3: 148-161.

Hallerberg, Marc, and Jürgen von Hagen. 1999. Electoral institutions, cabinet negotiatons, and budget deficits in the European Union. In Fiscal institutions and fiscal performance, eds. James Poterba, and Jürgen von Hagen, 209-232. Chicago: University of Chicago Press.

Hibbs, Douglas A. 1977. Political parties and macroeconomic policy. American Political Science Review 71 (4): 1467-1487.

Im, Kyung So, M Hashem Pesaran, and Yongcheol Shin. 2003. Testing for unit roots in heterogenous panels. Journal of Econometrics 115 (1): 53-74. 
Keman, Hans. 2000. Federalism and policy performance. In Federalism and political performance, ed. Ute Wachendorfer-Schmidt, 196-227. London/New York: Routledge.

Kirchgässner, Gebhard, and Werner W. Pommerehne. 1996. Die Entwicklung von öffentlichen Finanzen in föderativen Systemen. In Staatsaufgaben, ed. Dieter Grimm, 149-176. Frankfurt am Main: Suhrkamp.

Kittel, Bernhard. 1999. Sense and sensitiveness in pooled analysis of political data. European Journal of Political Research 35 (2): 225-253.

Kittel, Bernhard, and Hannes Winner. 2005. How reliable is pooled analysis in political economy? The globalization-welfare state nexus revisited. European Journal of Political Research 44 (2): 269-293.

Ladner, Andreas. 1994. Finanzkompetenzen der Gemeinden. Ein Überblick über die Praxis. In Finanzföderalismus, eds. Franz Eng, Alexander Glatthard, and Beat H. Koenig, 64-85. Bern: Emissionszentrale der Schweizer Gemeinden.

Lancaster, Thomas D., and Alexander M. Hicks. 2000. The impact of federalism and neo-corporatism on economic performance. In Federalism and political performance, ed. Ute Wachendorfer-Schmidt, 228-242. London/New York: Routledge.

Lane, Jan Erik. 2001. The Swiss labyrinth: Institutions, outcomes and redesign. London/ Portland: Frank Cass.

Lane, Jan Erik, and Svante O. Ersson. 1997. Is federalism superior?. In Political institutions and public policy. Perspectives on European decision making, eds. Bernard Steunenberg, and Frans van Vught, 85-113. Dordrecht: Kluwer Academic Publishers.

Laufer, Heinz, and Ursula Münch. 1998. Das föderative System der Bundesrepublik Deutschland. Opladen: Leske + Budrich.

Lijphart, Arend. 1999. Patterns of democracy. Government forms and performance in thirty-six countries. New Haven/London: Yale University Press.

Linder, Wolf. 2005. Schweizerische Demokratie. Institutionen, Prozesse, Perspektiven. Bern/ Stuttgart/Vienna: Haupt.

Lüchinger, Simon, and Alois Stutzer. 2002. Skalenerträge in der öffentlichen Verwaltung. Swiss Political Science Review 8 (1): 7-49.

McKay, David. 2001. A designing Europe: Comparative lessons from the federal experience. Oxford: Oxford University Press.

Moser, Christian. 1983ff. Abstimmungen, Initiativen und fakultative Referenden in den Kantonen. Bern: Forschungszentrum für Politik.

Nüssli, Kurt. 1985. Föderalismus in der Schweiz. Chur: Rüegger.

Oates, Wallace. 1999. An essay on fiscal federalism. Journal of Economic Literature 37 (3): $1120-1149$.

Obinger, Herbert. 1997. Institutionen und Sozialpolitik. Das Beispiel Schweiz. Österreichische Schweizerische Zeitschrift für Politikwissenschaft 26 (2): 149-164. 
1998. Politische Institutionen und Sozialpolitik in der Schweiz. Der Einfluss von Nebenregierungen auf Struktur und Entwicklungsdynamik des schweizerischen Sozialstaates. Frankfurt am Main/New York/Paris/Vienna: Lang.

Przeworski, Adam, and Henry Teune. 1970. The logic of comparative social inquiry. New York: Wiley-Interscience.

Riker, William H. 1964. Federalism: Origins, operation, and significance. Boston: Little: Brown and Company.

1975. Federalism. In Handbook of political science, 5, ed. Fred I Greenstein, 93-172. Reading, MA: Addison-Wesley.

Rodden, Jonathan. 2002. The dilemma of fiscal federalism. Grants and fiscal performance around the world. American Journal of Political Science 46 (3): 670-687.

Rodden, Jonathan. 2003. Reviving Leviathan: Fiscal federalism and the growth of Government. International Organisation 57: 695-729.

. 2004. Comparative federalism and decentralization. On meaning and measurement. Comparative Politics 2: 481-500.

- 2006a. Hamilton's Paradox: The promise and peril of fiscal federalism. Cambridge: Cambridge University Press.

- 2006b. The political economy of federalism. In Oxford handbook of political economy, ed. Barry R Weingast, 234-267. Oxford: Oxford University Press.

Rodden, Jonathan, and Erik Wibbels. 2002. Beyond the fiction of federalism. Macroeconomic management in multi-tiered systems. World Politics 54 (3): 494-531.

Rodden, Jonathan, and Gunnar Eskeland, Jennie Litvack, ed. 2003. Fiscal decentralization and the challenge of hard budget constraints. Cambridge: MIT Press.

Roubini, Nouriel, and Jeffrey Sachs. 1989. Political and economic determinants of budget deficits in the industrial countries. European Economic Review 33 (5): 903-933.

Schaltegger, Christoph A. 2001. Ist der Schweizer Föderalismus zu kleinräumig?. Schweizerische Zeitschrift für Politikwissenschaft 7 (1): 1-18.

2003. Föderalismus und Staatstätigkeit? Zeitschrift für Wirtschaftspolitik 52 (1): $84-110$.

Schaltegger, Christoph A., and Lars P. Feld. 2003. Die Zentralisierung der Staatstätigkeit in einer Referendumsdemokratie. Evidenz aus der Schweiz. Politische Vierteljahresschrift 44 (3): 370-394.

Scharpf, Fritz W. 1987. Sozialdemokratische Krisenpolitik in Europa. Frankfurt am Main/ New York: Campus.

- 1994. Optionen des Föderalismus in Deutschland und Europa. Frankfurt am Main/ New York: Campus.

Schmidt, Manfred G. 1998. Sozialpolitik in Deutschland: historische Entwicklung und internationaler Vergleich. Opladen: Leske + Budrich. 
2 2000. Die sozialpolitischen Nachzüglerstaaten und die Theorien der vergleichenden Staatstätigkeitsforschung. In Der gezügelte Wohlfahrtstaat. Sozialpolitik in reichen Industrienationen, ed. Herbert Obinger, 22-36. Frankfurt am Main/New York: Campus.

Schuler, Martin. 1997. Die Raumgliederung der Schweiz. Bern: Bundesamt für Statistik.

Shadbegian, Ronald J. 1999. Fiscal federalism, collusion, and government size. Evidence from the States. Public Finance Review 27 (3): 262-281.

Sinn, Hans-Werner. 1997. Das Selektionsprinzip und der Systemwettbewerb. Schriften des Vereins zur Socialpolitik 253: 9-60.

Stein, Ernesto. 1999. Fiscal decentralization and government size in Latin America. Journal of Applied Economics 2: 357-391.

Stutzer, Alois. 1999. Demokratieindizes für die Kantone der Schweiz. Institut für Empirische Wirtschaftsforschung Working Paper No. 23, Zurich.

Stutzer, Alois, and Bruno S. Frey. 2000. Stärkere Volksrechte - Zufriedene Bürger. Eine mikroökonometrische Untersuchung für die Schweiz. Schweizerische Zeitschrift für Politikwissenschaft 6 (3): 1-30.

Tiebout, Charles M. 1956. A pure theory of local expenditure. Journal of Political Economy 64 (5): 416-424.

Tsebelis, George. 2002. Veto players. How political institutions work. New York: Sage.

Vatter, Adrian. 1999. Föderalismus in der Schweiz. In Handbuch der Schweizer Politik, eds. Ulrich Klöti, Peter Knoepfel, Hanspeter Kriesi, Wolf Linder, and Yannis Papadopoulos, 77-108. Zurich: NZZ.

- 2002. Kantonale Demokratien im Vergleich. Entstehungsgründe, Interaktionen und Wirkungen politischer Institutionen in den Schweizer Kantonen. Opladen: Leske + Budrich.

- 2007. The cantons. In Handbook of Swiss politics, eds. Ulrich Klöti, Peter Knoepfel, Hanspeter Kriesi, Wolf Linder, and Yannis Papadopoulos, 197-224. Zurich: NZZ.

Wagschal, Uwe. 1996. Staatsverschuldung. Ursachen im internationalen Vergleich. Opladen: Leske + Budrich.

—. 2003. Wer ist Schuld an den Schulden? Zur Politischen Ökonomie der Staatsverschuldung. In Politische Ökonomie. Demokratie und wirtschaftliche Leistungsfähigkeit, eds. Herbert Obinger, and Uwe Wagschal, 289-319. Opladen: Leske + Budrich.

Watts, Ronald L. 1999. Comparing federal systems. Montreal: McGill-Queen's University Press.

Wibbels, Erik. 2000. Federalism and the politics of macroeconomic policy and performance. American Political Science Review 44 (4): 687-702.

Weingast, Barry. 1995. The economic role of political institutions. Market preserving federalism and economic development. Journal of Law, Economics, and Organization 11 (1): 1-31. 